\title{
PHYTOTOXIC INFLUENCE OF Tectona grandis L. ON GERMINATION, GROWTH AND BIOCHEMICAL CHANGES OF Solanum lycopersicum L. AND Solanum melongena L.
}

\author{
K. Edwina ${ }^{1}$ and P. Leela ${ }^{2}$, \\ ${ }^{1}$ Research Scholar, (Reg. No: 19211172262019) Department of Botany, PG Research \\ Department, Rani Anna Government College for Women, Tirunelveli-8, Tamil Nadu, India \\ (Affiliated to Manonmanium Sundaranar University, Tirunelveli, Tamil Nadu, India.) \\ ${ }^{2}$ Department of Botany, Annamalai University, Tamil Nadu, India. \\ ${ }^{\circledR}$ Corresponding Author: leeladde72@gmail.com
}

\begin{abstract}
The study aims to investigate the phytotoxic influence on seed germination and biochemical changes of two Solanceace family crops Solanum lycopersicum L. and Solanum melongena L. with different concentrations (20\%, $15 \%, 10 \%, 5 \%, 2 \%$ ) of aqueous leaf extract of Tectona grandis L. The effect of different concentrations of teak leaf extract was compared with control(water). Decreased germination percentage, shoot, and radicle length of the crops were observed to be concentration dependent. All the different extract concentrations caused an inhibitory and stimulatory effect on the crops' germination and morphogenesis compared to control. Biochemical changes and Phytochemical screening of the $T$. grandis leaf extract were equally determined. By this treatment, $S$. lycopersicum showed a more inhibitory effect than $S$. melongena.
\end{abstract}

Keywords: Allelopathy, Tectona grandis, Germination, Phytochemicals, Extract.

RASĀYAN J. Chem., Vol. 14, No.2, 2021

\section{INTRODUCTION}

Phytotoxic compounds produced by higher plants are mostly secondary metabolites. Phenolics, quinones, lactones, cyanogenic glycosides, organic acids and volatile terpenes belong to the most active compounds. These compounds are released into neighbouring environments through root exudation, volatilization, leaching and decomposition of plants, and inhibit the growth of neighbouring plants. ${ }^{1}$ These chemical substances may inhibit or stimulate the associated plant growth. ${ }^{2}$ Elroy ${ }^{3}$ reported that the positive or negative effect on another microorganism by liberating biochemical (allelochemicals) into the environment is Allelopathy. Allelopathic chemicals can be present in any part of the plant- leaves, flowers, roots, fruits, or stems and even in the surrounding soil. Florentine and Fox ${ }^{4}$ mentioned that allelochemicals play a significant role in suppressing weed plants' growth in many ways. Nelson ${ }^{5}$ stated that plants' interaction through chemical signals 'allelopathy' has many agricultural and ecological applications. In-allelopathy, the more common inhibitor effects are upon respiration; photosynthesis; water balance and stomatal function; stem conductance of water; cell division and development xylem element flux; membrane permeability; protein synthesis; and enzyme activity alteration. Laboratory bioassays for phytotoxicity/allelopathy are becoming more standardized so that significant comparisons can be made between the allelopathic potentials of diverse plants. ${ }^{6}$ Hamavun et al. ${ }^{7}$ observed that different plant species impose a distinct allelopathic effect on recipient plants.

Allelopathy has been studied over the past 50 years, but only a few studies have attempted to understand allelochemical interactions among plants in the context of these broader effects. ${ }^{8-12}$ Several areas of allelopathy have been studied, and some studies are in progress. Moreover, some areas are required to be studied to implicate the mechanism of allelopathy successfully. The potency of competition between agroforestry trees and crops for space, light, moisture, and nutrient will differ under various field conditions, affecting the allelopathic potentiality.

Agroforestry is the growing of both trees and crops on the same piece of land. In the agroforestry system, the yield of crops may be reduced due to competition and allelopathic interaction with trees. However, its 
RASĀYAN J. Chem.

influence varies with tree crop combination. Such inhibitory effects on the understory vegetation have been exhibited in pines. ${ }^{13}$ The reduced yield of most crops in an agroforestry system is due to tree species' allelopathic effect. The phytotoxic chemicals are classified mainly as secondary metabolites (such as alkaloids, isoprenoids, phenolics, flavonoids, terpenoids, etc. ${ }^{14}$ For this study, teak is selected as the agroforestry tree to determine the allelopathic effect on various crops. Teak (Tectona grandis), a critical agroforestry tree, is primarily farmed in India's tropical regions and other south Asian countries for its valuable and useful quality timber. It is a massive deciduous tree of the family Verbenaceae. The species is reported to cause some allelopathic effects. ${ }^{15-19}$ The teak plant has some allelochemicals that inhibit seed germination and seedling growth of other plants or target plants.

In the present study, Solanum lycopersicum (Tomato) and Solanum melongena (Eggplant), are selected to study the allelopathic effect of Tectona grandis. Tomato and Eggplant belong to the same family Solanaceae. Tomato antioxidants defend against a variety of deadly diseases, including cancer, diabetes, and heart disease, to name a few. Tomatoes are rich in vitamin $\mathrm{C}$ and, as a result, in the phytochemical lycopene. The fruits are commonly used in salads, as a cooked vegetable, as an ingredient in a variety of prepared dishes, and as a pickle. S. melongena contains phenolic compounds, which are antioxidants. Eggplants contain potassium, vitamin C, vitamin B-6, fiber, and antioxidants, all of which are beneficial to heart health. Polyphenols found in eggplant can help the body battle cancer. Anthocyanins and chlorogenic acid protect cells from damage caused by free radicals. This study aims to determine the allelopathic potential of Tectona grandis, a common woody tree widely grown in Tamil Nadu's Tirunelveli District, on tomato and eggplant vegetable crops. Many farmers will benefit from this knowledge when choosing better tree varieties for agroforestry. The study aims to see how different concentrations of aqueous extract of $T$. grandis leaf influence the germination, morphological, and biochemical growth of $S$. lycopersicum and $S$. melongena.

\section{EXPERIMENTAL}

\section{Study Area}

A greenhouse study was conducted at PG Research Department of Botany, Rani Anna Govt. college for women, Tirunelveli District on Longitude $8.7139^{\circ} \mathrm{N}$ and Latitude $77.7567^{\circ} \mathrm{E}$.

\section{Preparation of the Aqueous Leaf Extract}

Fresh leaf samples of $T$. grandis were collected at the vegetative stage from Tirunelveli districts of Tamil $\mathrm{Nadu}$. Then the leaves were shade dried and were grounded by using mortar and pestle and passed through a $2 \mathrm{~mm}$ mesh sieve. In a $1000 \mathrm{ml}$ conical flask, different quantities of ground teak leaves $(20 \mathrm{~g} / 1000 \mathrm{ml}$, $15 \mathrm{~g} / 1000 \mathrm{ml}, 10 \mathrm{~g} / 1000 \mathrm{ml}, 5 \mathrm{~g} / 1000 \mathrm{ml}$, and $2 \mathrm{~g} / 1000 \mathrm{ml})$ were dissolved in sterilized distilled water. The percentages of leaf extracts were 20 percent, 15 percent, 10 percent, 5 percent, and 2 percent, with water as a control. The mixture was then shaken at regular intervals and allowed to stand at room temperature for 24 hours. Later, layers of muslin cloth and No. 1 Whatman filter paper were used to filter the suspensions. ${ }^{20}$

\section{Collection, Sterilization of Seeds and Germination Study}

The certified seeds of Tomato (Solanum lycopersicum L. - CO-3) and Eggplant (Solanum melongena L.PLR. 1) were gained from Tamil Nadu Agricultural University, Coimbatore. Earthern Pots $(40 \times 25 \mathrm{~cm})$ were filled with garden soil having silt, humus, and sand (pH-7.3, N- 0.13, P- 0.29, K - 0.09, and OC-1.86\%). Healthy and uniform Tomato and Eggplant seeds were chosen. The seeds were sterilized for 15 minutes with 1 percent sodium hypochlorite, then rinsed thoroughly with distilled water to remove the excess chemical and dried to prevent fungal attacks. The seeds were presoaked for two hours in distilled water before being soaked for three hours in various amounts of aqueous leaf extracts. The crop seeds were then sown@ 20/ Pots and uniformly irrigated with different concentrations of T. grandis aqueous leaf extracts, and three replicates of each procedure, including control, were retained. Distilled water was used to irrigate the control pot. On the seventh day after the seed was sown, germination was observed. On the 15th day after germination, growth parameters such as root length, shoot length, dry biomass, and biochemical constituents of test crop seedlings such as chlorophylls, carotenoids, sugars, starch, protein, amino acids, and enzymes were measured. All measurements were taken on samples that were drawn five times and repeated. 
RASĀYAN J. Chem.

Vol. 14 | No. 2 |1191-1198| April - June | 2021

\section{Phytochemical Screening}

A round bottom flask containing $200 \mathrm{~cm}^{3}$ of methanol was filled with $30 \mathrm{~g}$ of powdered leaves and mixed. The flask was put in a flask shaker and agitated for four hours before being set aside overnight. The extract was then filtered and tested for bioactive components using phytochemical tests..$^{21-23}$

\section{Statistical Analysis}

Statistical analysis was performed employing a one-way analysis of variance (ANOVA). The least significant test was used at $5 \%$ to identify significant variations between means. All values are expressed as mean \pm variance.

\section{RESULTS AND DISCUSSION}

T. grandis had both inhibitory and stimulatory allelopathic effects on S. lycopersicum L. and S. melongena, according to the findings. Every day after treatment, the number of seeds that germinated was counted, and the total was used to measure the final germination percentage in each treatment. Seed germination of $S$. lycopersicum and S.melongena showed no significant differences when treated with lower concentrations (5\% and $10 \%$ ) of $T$. grandis leaf extract, but the leaf extract at $20 \%$ concentration caused a significant reduction in germination (Table-1). The leaf extract of $T$. grandis significantly reduced the $S$. lycopersicum germination above $2 \%$ concentration in both test species, the leaf extract at a concentration of $2 \%$ extract does not decrease germination but increases germination percentage. The germination of test species was significantly decreased by $T$. grandis leaf extract, and this inhibition was concentration dependent. Ferreira ${ }^{24}$ studied that changes in the germination process may be caused by membrane permeability, DNA transcription, protein translation, secondary messengers activity, metabolism, enzyme conformation and receptors in the membranes, or joint action of these changes. When treated with water extracts of $C$. odorata leaves and stems, Adetayo et al. ${ }^{25}$ found that cowpea and soybean seed germination was reduced by $14 \%$ and $8 \%$, respectively. The delay in seed germination can have major biological and ecological effects, according to Chaves et al. ${ }^{26}$, since it can affect seedlings' ability to develop themselves in natural conditions. With increasing concentrations of aqueous extracts, decreasing water absorption by $S$. lycopersicum and $S$. melongena seeds could indicate the impact of $T$. grandis leaf allelopathy on seed imbibition, the leading factor in delaying or decreasing germination of test plants. Chon et al. ${ }^{26}$ reported in their study the inhibition of water uptake by allelopathic species.

Table-1: Seed Germination

Allelopathic Influence of Tectona grandis Leaf Extracts on Germination (\%) of Solanum lycopersicum and Solanum melongena

\begin{tabular}{c|c|c}
\hline $\begin{array}{c}\text { Extract } \\
\text { Concentration }\end{array}$ & S. lycopersicum & S. melongena \\
\hline Control & 92 & 95 \\
\hline $2 \%$ & $96(4.3)$ & $99(4.2)$ \\
\hline $5 \%$ & $90(-2.2)$ & $97(2.1)$ \\
\hline $10 \%$ & $76(-17.4)$ & $83(-12.6)$ \\
\hline $15 \%$ & $58(-37.0)$ & $65(-31.6)$ \\
\hline $20 \%$ & $33(64.1)$ & $42(-55.8)$ \\
\hline
\end{tabular}

Data in parentheses indicate \% increase/decrease over control.

On the 20th day after the seed was sown, shoot length (Fig.-1) was measured from the soil level to the upper point of the seedling's terminal bud, and root length was measured from the soil level to the lower point of the root tip using a meter ruler. When $2 \%$ leaf extract was used, two test species stimulated the root length ( $8.57 \%$ in S. lycopersicum and $13.04 \%$ in S. melongena) and shoot length (5.95\% in S. lycopersicum and S. melongena $6.79 \%$ ) moreover control. 
RASĀYAN J. Chem.

Vol. 14 | No. 2 |1191-1198| April - June | 2021

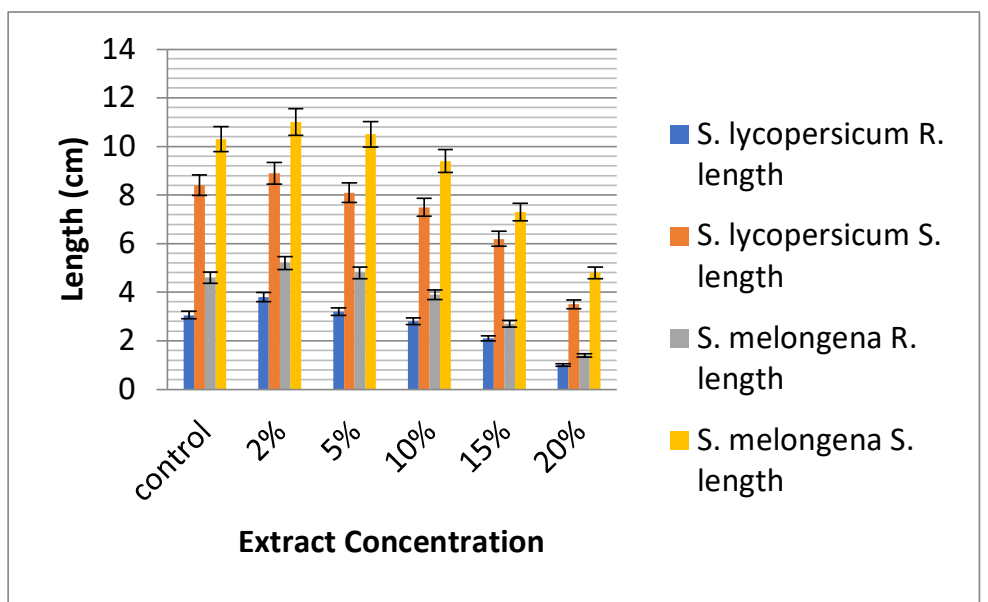

Fig.-1: Allelopathic Influence of T. grandis Leaf Extracts on Root Length(cm/seedling) and Shoot Length(cm/seedling) of Solanum lycopersicum and Solanum melongena

Table-2: Allelopathic Influence of T. grandis Leaf Extracts on Fresh Weight (mg/seedling) and Dry Weight (mg/seedling) of Solanum lycopersicum and Solanum melongena

\begin{tabular}{c|c|c|c|c}
\hline \multirow{2}{*}{$\begin{array}{c}\text { Extract } \\
\text { Concentration }\end{array}$} & \multicolumn{2}{|c|}{ S. lycopersicum } & \multicolumn{2}{c}{ S. melongena } \\
\cline { 2 - 5 } & $\begin{array}{c}\text { Fresh weight } \\
\text { (mg/plant) }\end{array}$ & $\begin{array}{c}\text { Dry weight } \\
\text { (mg/plant) }\end{array}$ & $\begin{array}{c}\text { Fresh weight } \\
\text { (mg/plant) }\end{array}$ & $\begin{array}{c}\text { Dry weight } \\
\text { (mg/plant) }\end{array}$ \\
\hline Control & 3.06 & 0.25 & 3.24 & 1.25 \\
\hline $2 \%$ & $3.10(1.3)$ & $0.27(8.0)$ & $3.53(9.0)$ & $1.30(4.0)$ \\
\hline $5 \%$ & $2.75(-10.3)$ & $0.21(-16.0)$ & $3.30(1.9)$ & $1.23(-1.6)$ \\
\hline $10 \%$ & $2.06(-32.7)$ & $0.19(-24.0)$ & $2.89(-10.8)$ & $0.99(-20.8)$ \\
\hline $15 \%$ & $1.45(-52.6)$ & $0.11(-56.0)$ & $2.25(-30.6)$ & $0.75(-40.0)$ \\
\hline $20 \%$ & $0.80(-73.9)$ & $0.07(-72.0)$ & $1.40(-56.8)$ & $0.27(-68.0)$ \\
\hline
\end{tabular}

Data in parentheses indicate \% increase/decrease over control.

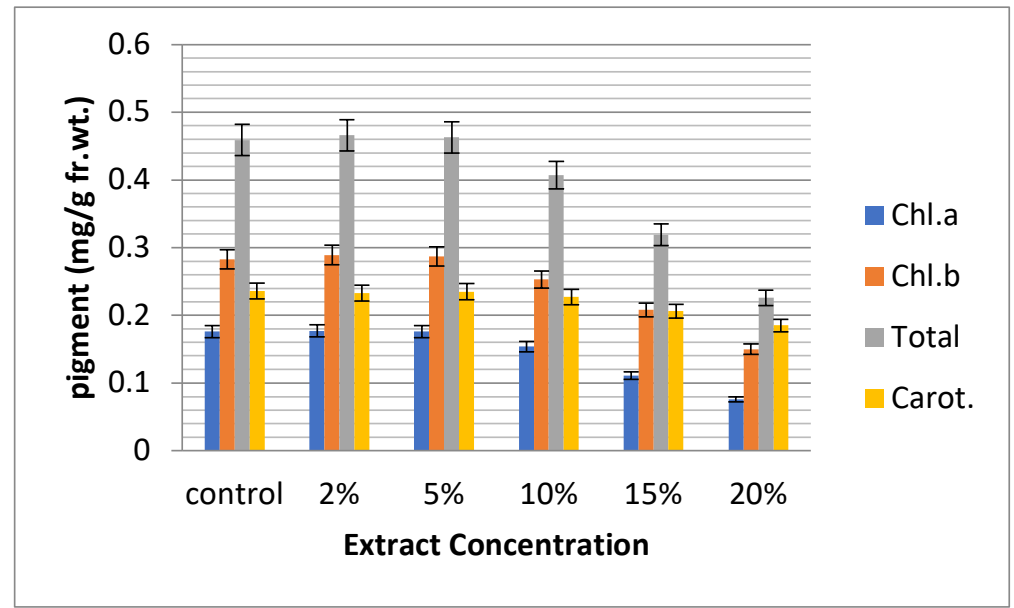

Fig.-2: Allelopathic Influence of T. grandis Leaf Extract on Chl.a, Chl.b and Total Chlorophyll and Carotenoids (mg/g fr.wt.) of $S$. lycopersicum.

These results showed the stimulatory and inhibitory effects of $T$. grandis on tomato and eggplant. Eucalyptus leaf extracts inhibited seed germination and seedling development in some herbaceous plants, according to Siddiqui et al. ${ }^{28}$ Their work is in support of this research. Allelochemicals contained in T.grandis leaf extract include phenol, steroids, Tannin, flavonoids, saponin, coumarins, leucoanthocyanin, alkaloids, amino acids, proteins, and others. These secondary metabolites strongly inhibited all the stages of mitosis of the root cells and shoot cells. 
RASĀYAN J. Chem.

Vol. 14 | No. 2 |1191-1198| April - June | 2021

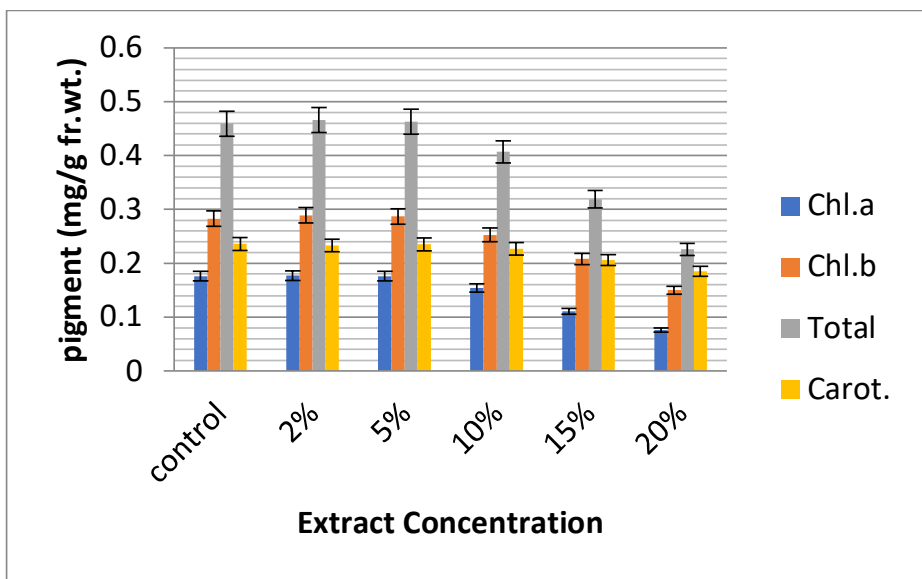

Fig.-3: Allelopathic Influence of T. grandis Leaf Extract on Chl.a, Chl.b and Total Chlorophyll and Carotenoids (mg/g fr.wt.) of $S$. melongena.

Table-3: Allelopathic Influence of T. grandis Leaf Extracts on Starch, Protein, Amino Acid and Sugar (mg/g fr.wt.) of S. lycopersicum and S. melongena

\begin{tabular}{c|c|c|c|c|c|c|c|c}
\hline \multirow{2}{*}{$\begin{array}{c}\text { Extract } \\
\text { Concentrations }\end{array}$} & \multicolumn{4}{|c|}{ S. lycopersicum } & \multicolumn{4}{c}{ S. melongena } \\
\cline { 2 - 9 } & Starch & Protein & $\begin{array}{c}\text { Amino } \\
\text { acid }\end{array}$ & Sugar & Starch & Protein & $\begin{array}{c}\text { Amino } \\
\text { acid }\end{array}$ & Sugar \\
\hline \multirow{2}{*}{ Control } & 0.372 & 0.754 & 0.211 & 0.145 & 0.411 & 0.223 & 0.296 & 0.018 \\
& & & & & & & & \\
\hline $2 \%$ & 0.389 & 0.757 & 0.215 & 0.148 & 0.418 & 0.230 & 0.304 & 0.021 \\
& $(3.4)$ & $(0.4)$ & $(1.9)$ & $(2.0)$ & $(1.7)$ & $(3.1)$ & $(2.7)$ & $(16.7)$ \\
\hline $5 \%$ & 0.372 & 0.740 & 0.204 & 0.131 & 0.416 & 0.227 & 0.297 & 0.019 \\
& $(-1.1)$ & $(-1.9)$ & $(-3.3)$ & $(-9.7)$ & $(1.2)$ & $(1.8)$ & $(0.3)$ & $(5.6)$ \\
\hline $10 \%$ & 0.340 & 0.718 & 0.185 & 0.106 & 0.390 & 0.215 & 0.282 & 0.013 \\
& $(-9.6)$ & $(-4.8)$ & $(-12.3)$ & $(-26.9)$ & $(-5.1)$ & $(-3.6)$ & $(-4.7)$ & $(-27.8)$ \\
\hline $15 \%$ & 0.305 & 0.680 & 0.163 & 0.080 & 0.367 & 0.184 & 0.255 & 0.009 \\
& $(-18.9)$ & $(-9.8)$ & $(-22.7)$ & $(-44.8)$ & $(-10.7)$ & $(-17.5)$ & $(-13.9)$ & $(-50.0)$ \\
\hline $20 \%$ & 0.247 & 0.627 & 0.122 & 0.041 & 0.326 & 0.129 & 0.209 & 0.005 \\
& $(-34.3)$ & $(-16.8)$ & $(-42.2)$ & $(-71.7)$ & $(-20.7)$ & $(-42.2)$ & $(-29.4)$ & $(-72.2)$ \\
\hline
\end{tabular}

Data in parentheses indicate \% increase/decrease over control.

Changes in DNA synthesis in the nucleus were responsible for the inhibitory effect. As a result, the length and growth of seedlings in the test species were affected. According to Abrahim ${ }^{29}$, -pinene is even more toxic and lipophilic. As a result, these chemicals can easily penetrate mitochondrial membranes, causing respiratory problems. Sarmin ${ }^{30}$ investigated the relationship between Moringa oleifera and Triticum aestivum by using five different concentrations of Moringa leaf, bark, and root extracts $(0 \%$, i.e., freshwater, $25 \%, 50 \%, 75 \%$, and $100 \%$ ) to research the impact on germination and growth of Triticum aestivum. The results of the present study were similar to those of Muoghalu and Chuba ${ }^{31}$, Zachariades et $a l .{ }^{32}$ who found that different concentrations of $C$. odorata leaf aqueous extract significantly inhibited the germination, root and shoot elongation and development of lateral roots of Cicer arietinum, Brassica juncea, Cucumis sativus, Phaseolus mungo, Raphanus sativus, and Vigna unguiculata L. Walp.

The Teak leaf extract treatments reduced the fresh and dry weight of the test crop seedling. The degree of inhibition depends on the concentrations of the extracts. The more reduction of fresh weight and dry weight of S. lycopersicum and S. melongena at 20\% extract concentration were $73.8 \%, 56.8 \%$ (fresh weight), and $72.0 \%, 64.8 \%$ (dry weight) respectively. A more inhibitory effect was observed in S. lycopersicum seedlings than $S$. melongena seedlings. Zohabib et $a l^{33}$ found that profuse allelochemicals hinder seed germination, plant growth, and biomass production through disruption of various physiological functions taking place within the plant body. This present study is paralleled with their study. The findings of this study matched those of Malik ${ }^{34}$, El-Khawas and Shehata ${ }^{35}$, and Yamagushi. ${ }^{36}$ The stem and whole plant 
RASĀYAN J. Chem.

extract of Trianthema portulacastrum reduced the dry matter yield on Soybean, according to Umarani and Selvaraj. ${ }^{37}$ The presence of a higher concentration of volatiles, chemicals, or phenolic compounds could be inhibiting seedling length and biomass. The current research backs up del Moral and Muller's earlier findings. ${ }^{38}$ S. lycopersicum treated with $T$. grandis $20 \%$ concentration of leaf extracts showed the most severe adverse effect, followed by $15 \%, 10 \%, 5 \%$, and $2 \%$. The results of Phytochemical analysis showed the presence of Phenol, flavonoids, amino acids, alkaloids, steroids, Tannin, Protein, saponin, coumarins, phytosterol, leucoanthocyaninn, chalcone, propanal, butanal, acetic anhydride, formic acid, 2-pentanone, propanoic acid, butanoic acid, etc. in $T$. grandis.

The biochemicals studies of S. lycopersicum and S. melongena like chl-a, ch-.b, Total chlorophyll, starch, protein, sugar, and amino acids were determined after 25 days of germination. The highest decreasing percentage was noticed at $20 \%$ extract concentrations in both test crops. In tomato chl- $\mathrm{b}$ and protein reduction percentage was barely noticed than eggplant seedlings. At the same time, the observed amino acid and starch reduction percentage in S. melongena was significantly less at $20 \%$ extract treatment. Results were found that were similar to Venkateshwarlu's findings ${ }^{39}$, who reported inhibition in chlorophyll $\mathrm{a}$ and chl. b content ( $41.66 \%$ and $11.36 \%$, respectively) in radish when treated with $M$. indica leaf extract (200 ppm). The decrease in chlorophyll content observed in a few combinations may be due to the degradation or reduction in synthesis of chlorophyll pigments, as well as the action of flavonoids, terpenoids, or other phytochemicals present in leaf extracts. ${ }^{40}$ Reduction in chlorophylls may decrease the photosynthesis, resulting in a significant reduction in all metabolites, including total sugars, proteins, and soluble amino acids. ${ }^{41}$

The $20 \%$ extract treatment had the strongest inhibitory effect, followed by $15 \%, 10 \%$, and $5 \%$ extract treatments when compared to the control. The solvent extract (water) had the most allelopathic effects on the test species' germination and seedling growth, according to this report. With rising concentration, inhibition increased. These results agree with those obtained by Mohamadi and Rajaie ${ }^{42}$ that studied the effect of leaf extract of $E$. camaldulensis on sorghum and kidney bean. Abdalla ${ }^{43}$ reported that fertilization of Eruca vesicaria plants with 2\% leaf and 3\% twig aqueous extracts of Moringa oleifera potentially increased the plant height, fresh and dry herb weight, photosynthetic rates, stomatal conductance, chlorophyll a and $\mathrm{b}$, carotenoids, total sugars, total protein, phenols, ascorbic acid, nitrogen, phosphorus, potassium, calcium, magnesium, iron as well as growth-promoting hormones (auxins, gibberellins, and cytokinins) Tithonia diversifolia (Hemsl) A. Gray and Chromolaena odorata (L.). The present work also supported Abdalla's work. Djanaguiraman et al ${ }^{44}$ found that chlorophyll conversion intolerant species chla to chlorophyll $-\mathrm{b}$ may occur during stressful situations. At more elevated concentrations, allelochemicals may act as photosynthetic inhibitors that block electron acceptors, act as energy uncouplers, and reduce photosynthetic pigments and enzymes. ${ }^{45}$ Otusanya et al. ${ }^{46}$ reported water root exudates of $T$. diversifolia significantly inhibited the germination, growth, and chlorophyll accumulation of tomato. Bais et al. ${ }^{47}$ revealed that allelochemicals could affect germination, growth, physiology, and even genetic factors of neighboring plants. Allelopathic inhibition is complicated and involves the interaction of allelochemicals like phenolic compounds, flavonoids, terpenoids, alkaloids, steroids, carbohydrates, and amino acids, with mixtures of various compounds. Allelopathic effects can differ in severity, duration, and developmental stage during plant development, according to studies. The allelopathic effect refers to the inhibitory and stimulatory effects of compounds obtained from a plant's metabolism products on another plant species.

\section{CONCLUSION}

The present investigation revealed that aqueous leaf extract of $T$. grandis at different concentration levels inhibited seedling growth while at low concentration stimulated the germination, seedling length, biomass, pigments, starch, protein and amino acid contents of $S$. lycopersicum (2\% extract treatment) and $S$. melongene $(2 \% \& 5 \%$ extracts treatment ) seedlings. Therefore, the study indicated the beneficial and adverse effects of Tectona leaf extract on S. lycopersicum and S. melongena. The inhibitory effect of various concentrations of the extract was unequal, showing the most violent inhibition in S. lycopersicum, while the lowest in S. melongena. The promotory effect was observed in eggplant seedlings in $2 \%$ and $5 \%$ extract concentration while in tomato seedlings, only at $2 \%$ extract concentration over control. Therefore this present study concluded that the stimulatory and inhibitory effect was based on the crop species and is not 
RASĀYAN J. Chem.

Vol. 14 | No. 2 |1191-1198| April - June | 2021

the same for all species. The inhibitory and stimulatory effects of $T$. grandis leaf extracts may be due to the presence of allelochemicals in the extracts. Between the two test crops, S. lycopersicum had a stronger inhibitory effect than S. melongena. Detailed field experiments are needed to better understand the potential soil-mediated physiological allelopathy and mode of action of individual allelochemicals from tree leaves on crop plants.

\section{REFERENCES}

1. R.G. Belz, Pest Management Science,63,308(2007), DOI:10.1002/ps. 1320

2. F.E. May, and J. E Ash, Australia Journal of Botany, 38,245(1990), DOI:10.1016/j.foreco.2014.03.004

3. L. Elroy, Allelopathy (Second Edition ed.), Academic Press, United Kingdom, 422 (1984).

4. S. K. Florentine, and J. E. D. Fox, Allelopathy Journal, 11, 77(2003), DOI: $10.1016 /$ j.foreco.2009.06.045

5. C. J. Nelson, Agronomy Journal, 88, 99(1996), DOI:10.3923/pjbs.2002.6.11

6. R.G. Belz and K. Hurle, Allelopathy Journal of Chemical Ecolology, 30(2004), DOI:10.1007/14020-4280-9 20

7. M. Hamayun, F. Hussain, S. Afzal and N. Ahmad, Pakistan Journal of Weed Science Research, 11, 81(2005).

8. R. Karban, Ecology Letters, 10, 791(2007), DOI:10.4161/psb.5.1.10160

9. K. L. Metlen, E.T. Aschehoug, and R. M. Callaway, Plant Cell Environment, 32, 641(2009), DOI: $10.1111 / \mathrm{j} .1365-3040.2008 .01910 . x$

10. Inderjit and J. Weiner, Plant Ecology Evolution Systematics, 4, 3(2001), DOI:10.1007/s11104004-0159-

11. D.H. Siemens, S. H. Gardbner, T. Mitchell-Olds, and Calla-way, Ecology, 83, 505(2002), DOI:10.1890/0012-9658(2002)083[0505:CODITC]2.0.CO;2

12. J. L. Pollock, T.R. Seastedt, R.M. Callaway, J. Kaur, and Inderjit, Biological Invasions, 10, 875(2009), DOI:10.1111/1365-2745.12619

13. E. L. Rice, Botanical Reviews, 45,15(1974)

14. T. Nazir, A. K. Uniyal and N. P. Todaria, Agroforestry System Journal, 69, 183(2007)

15. M. Jayakumar, M. Eyini, and S. Paneerselvam, Geobios Journal, 14, 66(1987), DOI: $10.3923 /$ ja.2003.92.100

16. F. A. Macias, R. Lacret, R. M. Varela, and C. Nogueiras, Proceedings of $2^{\text {nd }}$ Europe Allelopathy Sympossium, pp. 140, (2000).

17. R. Lalmuanpuii, and U. K. Sahoo, Scientific Visualization, 11(4), 208(2011).

18. C.R. Das, N. K. Mondal, A. Aditya, J. K. Datta, A. Banerjee,. and K. Das, Asian Journal of Experimental, Biological Sciences, 3(1), 59(2012), DOI:10.12989/aer.2015.4.1.001

19. A. Manimegalai, A. Manikandan, R. Sheela, and S. Geetha, International Journal of Current Science. Spl. Vol., 241 (2012).

20. J. W. Knox, Rodr'1guez, J. A. D'1az, D. J. Nixon and M. Mkhwanazi, Journal of Agricultural System, 103, 63(2010), DOI: 10.1088/1748-9326/7/3/034032

21. A. Bukar, and S.Y. Mudi, Biological and Environmental Sciences Journal for the Tropics, 8(1), 51(2011), DOI:10.9734/EJMP/2016/22443

22. S. Malviya, S. Rawat, M. Verma. and A. Kharia, Current Pharma Research, 1(2), 91(2011). DOI: $10.1007 / \mathrm{s} 41664-018-0071-7$

23. O. Sofowora, Medicinal Plants and Traditional Medicine in Africa. Spectrum Books Limited, Ibadan, Nigeria, pp.104(1993), DOI:10.5251/abjna.2011.2.3.476.487

24. A.G. Ferreira and M.E.A. Aquila, Revista Brasileira de Fisiologia Vegetal, 12,175(2000).

25. O. Adetayo, Lawal, B. Alabi, B. and O. Owolade, Proceedings of the 4thWorld Congress on Allelopathy, "Establishing the Scientific 257 Base", Wagga, New South Wales, Australia, pp.348351(2005), DOI:10.9790/2402-1203011524

26. N. Chaves, T. Sosa, and J.C. Escudero, Journal of Chemical Ecology 27, 623(2001), DOI: $10.1023 / \mathrm{A}: 1010388905923$

27. S. U. Chon, C. Nelsonand, J. Coutts, Agronomy Journal, 96, 1673(2004), DOI: 10.2134/agronj2004.1673 
RASĀYAN J. Chem.

Vol. 14 | No. 2 |1191-1198| April - June | 2021

28. S. Siddiqui, R. Yadav, K. Yadav and F.A. Wani, Global Journal of Molecular Sciences, 4(2), 91(2009).

29. D. Abrahim, W.L. Braguini, A.M. Kelmer-Bracht, and E. L. Ishii-Iwamoto, Journal of Chemical Ecology, 26, 611(2000), DOI:10.1023/A:1005467903297

30. Sarmin, Life Science Journal, 11(8), 41(2014).

31. J. I. Muoghalu and D.K. Chuba, Applied Ecology and Environmental Science Research, 3, 39(2005), DOI: $10.3390 /$ plants 9060766

32. C. Zachariades, Day, R. Muniappan and G.V.P Reddy, Biological Control of Tropical Weeds Using Arthropods (Cambridge University Press, Cambridge, UK, pp.130-(2009), DOI:10.1111/j.13652664.2011.02000.x

33. Zohaib, Tasawer Abbas and Tahira Tabassum, Notulae Scientia Biologicae, 8(81), 47(2016), DOI:10.15835/nsb.8.1.9752

34. M.S. Malik, Allelopathy Journal, 14, 213(2004), DOI:10.3923/pjbs.2007.3415.3419

35. S. A. El-Khawas and M. M. Shehata, Plant Biotechnology, 4(1), 23(2005), DOI: $10.1016 /$ j.foreco.2009.06.045

36. A. Q. Yamagushi, G. S. Gusman, and S. Vestana, Semina: Ciencias Agrarias, Londrina, 32(4), 1361(2011).

37. R. Umarani and J. A. Selvaraj, Allelopathy Journal, 3, 261(1996), DOI:10.2478/cerce-2018-0022

38. R. Del Moral, and C. H. Muller, American Midland Naturalist, 83, 254(1970), DOI:1007/BF00704926

39. G. Venkateshwarlu, V. Ravindra, and P. Challa, Allelopathy Journal, 8(2), 221(2001).

40. S. Tripathi, A. Tripathi, and D.C. Kori, Indian Journal of Forestry, 22, 366(1999).

41. N. B. Singh. and S. Ranjana, Allelopathy Journal, 11,43(2003), DOI:10.1016/j.indcrop.2014.03.011

42. N. Mohamadi and P. Rajaie, Research Journal of Biological Sciences, 4(12), 1291(2009), DOI:10.22161/ijfaf.1.4.4

43. Abdalla, M. Mona, Plants Academic Journal, 5(3), 42(2013), DOI:10.5897/IJPPB2012.026

44. M. A. Djanaguiraman, Senthil and R. Ramadass, Madras Agricultural Journal, 90, 506(2003), DOI: 10.1016/j.jbiotec.2019.07.003

45. F.A. Einhellig, and J.A. Rasmussen, Journal of Chemical Ecology, 5, 815(1979), DOI:10.1002/j.15372197.1975.tb12343

46. O.O. Otusanya, O. J. Ilori and A. A. Adelusi, Journal of Environmental Science, 1, 285(2008), DOI: $10.3923 /$ rjes.2007.285.293

47. H.P. Bais, R. Vepachedu, S. Gilroy, R.M. Callaway, J.M. Vivanco, Science, 301(5638), 1377(2003), DOI: $10.1126 /$ science. 1083245

[RJC-6285/2020] 